\title{
Assessment of Male Partner's Involvement in Prevention of Mother-to-Child Transmission of HIV and Associated Factors Among Males in PMTCT Services
}

\author{
Addis Adera ${ }^{1, ~ *, ~ M e s f i n ~ W u d u ~}{ }^{1}$, Yonas Yimam ${ }^{1}$, Markos Kidane², Ambachew Woreta ${ }^{3}$, \\ Tigabu Molla ${ }^{4}$ \\ ${ }^{1}$ Department of Nursing, Faculty of Health Sciences, Woldia University, North Wollo, Amhara Region, Ethiopia \\ ${ }^{2}$ Department of Economics, Faculty of Business and Economics, Unity University, Addis Ababa, Ethiopia \\ ${ }^{3}$ Department of Biology, Faculty of Natural and Computational Sciences, Woldia University, North Wollo, Amhara Region, Ethiopia \\ ${ }^{4}$ Department of Economics, Faculty of Business and Economics, Woldia University, North Wollo, Amhara Region, Ethiopia
}

\section{Email address:}

addisaderagebru@gmail.com (G. A. Addis)

\section{To cite this article:}

Addis Adera, Mesfin Wudu, Yonas Yimam, Markos Kidane, Ambachew Woreta, Tigabu Molla. Assessment of Male Partner's Involvement in Prevention of Mother-to-Child Transmission of HIV and Associated Factors Among Males in PMTCT Services. American Journal of Health Research. Vol. 3, No. 4, 2015, pp. 221-231. doi: 10.11648/j.ajhr.20150304.14

\begin{abstract}
Background: Maintaining an adequate and safe Prevention Mother-to-Child Transmission of HIV services and male partner's involvement in PMTCT services are an issue of concern to local health planner especially with increase in population size and an increase in the number of medical facilities. Objectives: To describes whether methodological issues such as sample Characteristics, Outcome measures, and mechanisms causing change in the outcome measures could explain some of the inconsistent findings evident on. Methods: This review bases peer reviewed journal articles on "Assessment of Male partner's involvement in Prevention of Mother-to-Child Transmission of HIV and Associated Factors among Males in PMTCT services." which are published between Sep, 2009 and February, 2015. Key words such as "Male partner", "PMTCT", "Male involvement", "ANC", "MTCT", and "HIV" were used to search the articles from different websites. A total of 106 articles were obtained. Then titles, summary or abstract, and the whole body of each of the articles were checked for their relevance to be included in the analyses. Finally, a total of 19 articles were found to be eligible to be included in the analyses. In this regards, we searched databases of MEDLINE, Pub Med. Elsevier, Google, BMC, PMC, and Psych Info search Engines. Result: From 106 identified studies, 19 met the inclusion criteria. The majority of the studies 7 (37. 1\%) identified the determinants of male partners' involvement in maternal and child health activities, focusing specifically on HIV prevention of maternal to child transmission (PMTCT) in Africa. Most of the reviewed articles 6 (31. 6\%) selected a minimum sample size of $100(20 \%)$ participants However, five of the total reviewed articles (26. 3\%) were selected the maximum sampled size of 500 participants. The study result reviewed studies sought to generalize from the mentioned articles by identifying a wide variety of male partner's involvement in PMTCT services and associated factors in PMTCT in Africa. Conclusion: Many challenges to increase male involvement in PMTCT (1) enhance male participation in the process, the adherence rate of mothers towards PMTCT care and support was fair, highlight the male participation in PMTCT programs, and male partner involvement in ANC/PMTCT is low. Male partner's involvement in PMTCT services is a well-accepted issue and has important positive outcomes on several of health discipline.
\end{abstract}

Keywords: Male Partner, PMTCT, Male Involvement, ANC, MTCT, HIV

\section{Introduction}

The most common route of transmissions for these infants is transmission from mother to child (MTCT) which occurs in up to $90 \%$ of cases (1). Male participation in child -bearing decisions is crucial and also has a positive impact on the acceptability of PMTCT interventions $(2,3)$. Without intervention, HIV can infect $25-45 \%$ of birth from HIV - 
positive mothers during pregnancy, delivery and/or breast feeding in developing countries and the efficacy of ARV drugs has been shown $(4,5)$. World health organization (WHO) promotes prevention of HIV infection, unintended pregnancies, perinatal HIV infection and providing care and support for HIV positive mothers and their families (6). Similar to other resources-poor nations facing the integration of PMTCT into routine pregnancy and infant care, efforts in South Africa to scale up PMTCT and reduce transmission to $<5 \%$ have fallen far short of the United Nation's goal of $50 \%$ reduction in pediatric HIV by $80 \%$ coverage of mothers (7). Involving male partners in ANC /PMTCT can often be utilized as an entry point for the provision of additional PMTCT services notably feeding testing, condom use and infant feeding recommendations for both male and female participants (8). Studies have shown that the utilization of PMTCT services by the pregnant women is influenced both by factors related to the health system such as accessibility of VCT services, and by individual factors such as fear of disclosures of HIV result, lack of male partners support, fear of domestic violence, abandonment and stigmatization $(9,10,11)$. Involvement of male partners in their partner's PMTCT program, in Tanzania and Kenya, led to more HIV infected women receiving Nevirapine during their antenatal follow up visits, adherence of breast feeding in their babies, adherence to infant feeding condom use than those whose partners were not involved (12). The proportion of pregnant women attending antenatal care whose male partners were tested for HIV was 5\% in 2008 versus $2 \%$ in 2007 (13). Mothersto -Child transmission (MTCT) is the most common route of HIV infection for HIV positive children under five years. It believed that with effective PMTCT interventions, MTCT can be reduced to levelsbelow5 \% (14). Men have a lot of power attached to their status in the family and the wider society. However, these attributes have becomes part of the barriers to male involvement in the uptake of PMTCT and low Utilization (15). Patient and health system factors are critical in determining success of PMTCT goals $(16,17)$. Providing highly active antiretroviral therapy to a woman will reduce viral replication and viral load during pregnancy, and as a post exposure prophylaxis, prevention infection in a new born $(18,19)$. In sub-Saharan Africa, antiretroviral (ARVs) coverage increased from $17 \%$ to $28 \%$, yet, despite recent progress, much work remains to be done. For instance, in 2008 an estimated 430, 000 children were newly infected with HIV, nearly all of them through MTCT (20). The main Purpose of this to describes whether methodological issues such as sample Characteristics, Outcome measures, and mechanisms causing change in the outcome measures could explain some of the inconsistent findings evident on male partner's involvement in PMTCT services and factors which affects in PMTCT services.

\section{Methods}

A review of the research literature is conducted in the area of Male partner's involvement in Prevention of Mother-to-Child Transmission of HIV and Associated Factors among Males in PMTCT services. The PUBMED, Ovid, Elsevier, Google Scholar, BMJ, MEDLINE, Science Direct and Web data was searched. This method used to determine the accuracy of the result by checking related articles with these various sources. This review based on peer review journal articles on "Assessment of Male partner's involvement in Prevention of Mother-to-Child Transmission of HIV and Associated Factors among Males in PMTCT services" which are published between Sep, 2009 and February, 2015 Because recent information and up to dated data was important to justify the reviewed and to addressed the objective of the review articles. After assessing all contents, titles, summary /abstracts, and full texts of articles, by excluding redundancy; meanwhile the relevancy of them to address the objectives of this study have been considered and evaluated. The term which was used for searching related articles "Male partner", "PMTCT", "Male involvement", "ANC", "MTCT", and "HIV" combined were used to search the articles from different websites. A total of 106 articles were obtained. Then titles, summary or abstract, and the whole body of each of the articles were checked for their relevance to be included in the analyses. Finally, a total of 19 articles were found to be eligible to be included in the analyses. The Authors conducted a reading of titles and made the decision to include articles in the review regarding the following criteria. The study included one or more instruments to gather information on Assessment of Male partner's involvement in Prevention of Mother-to-Child Transmission of HIV and Associated Factors among Males in PMTCT services. Articles published between Sep, 2009 and February, 2015, those with and those published in English were eligible for the analysis. Studies that didn't match criteria were excluded. Finally, given that some of the studies reviewed compare the previous activities Male involvement in PMTCT services with samples of all male partner's from different Health setting in worldwide identify characteristically implementation of PMTCT service in different health Institutes. All abstracts were eliminated from further consideration. For example, The titles, summary or abstract, and the whole body of each articles were then checked for their relevance and suitability to be included in the analyses were found to be eligible (Table 1). Formerly, we used the effective public health practice project quality Assessment Tool (EPHPP) (21). To assess the quality of quantitative research in this review. This instrument had ordinal scoring for the following components: Selection bias, study design, confounders, blinding, data collection methods, withdrawals and dropouts. Each components was rated strong, moderate, or weak and these ratings were also combined into a global quality rating (Strong, moderate or weak). Six reviewers assessed the quality, and discrepancies were resolved by discussion. 


\section{Result}

Out of 19 reviewed studies, 7 (37. 1\%) identified the determinants of male partners' involvement in maternal and child health activities, focusing specifically on HIV prevention of maternal to child transmission (PMTCT) in Africa $(22,27,29,30,31,34,36)$. Three studies $(15.9 \% 0$ assessed male involvement in prevention of mother-to-child transmission of HIV and associated factors among male partners in Africa (32, 38, 40); two studies (10. 6\%) described male involvement in programs for preventing mother-to-child transmission (PMTCT) in Africa (28). The remaining seven studies (37. 1\%) explored the views of participants on the factors that encourage, inconvenience or inhibit them in accompanying their wives to the ANC clinic (23), pointed out the role of male partner involvement on mother's adherence to PMTCT care (24), evaluated knowledge, attitude, communication behaviors among partners, awareness, and how they affect the uptake of the PMTCT services (25), investigated factors that affect access to and utilization of maternal and child health $(\mathrm{MCH})$ and PMTCT services among women (26), hypothesized that male partner HIV-1 counseling and testing during pregnancy 33), partner involvement and the uptake of prevention of PMTCT of HIV (PMTCT) interventions (35), and both explored and described male partner involvement in PMTCT services (39) respectively. The majority of reviewed articles 7 (36. 8\%) were conducted in $2014(23,24,29,31,32,36,39)$, followed by $3(15.8 \%)$ were conducted in $2013(28,35,40)$ and $3(15$. $8 \%)$ were conducted in $2012(22,33,37)$. Two studies $(10$. $6 \%$ were conducted in $2011(25,27)$ and $2(10.6 \%)$ were also conducted in $2010(30,38)$. The remaining two studies (10. 6\%) were conducted in 2009 (34) and 2015 (36) respectively. The studies included were all from developing countries (Africa). Five of the developing countries (26. 3\%) were conducted in Ethiopia $(24,26,16,19)$, Two in South Africa $(36,41)$, Sub-Saharan Africa $(22,28)$, Zambia $(23,29)$, Tanzania $(25,34)$, and Uganda $(30,40)$. The rest of the countries had one study in each : Malawi (31), Kenya (26), and Cameroon (33). Most of the included studies were noninterventional studies: Five were interview studies $(23,25,27$, $28)$; two studies were descriptive $(26,34)$, two were studies qualitative and Quantitative (9, 17); two were studied FGD and Interview $(8,16)$; and the remaining five were studies literature based review, (22), Randomized control trials (33), Retrospective cohort study (35), case control study (36), and institutional based CSS (40) respectively. The majority of the reviewed articles $(31.6 \%)$ selected a minimum sample size of $100(20 \%)$ participants $(22,23,28,31,37,39)$. However, five of the total reviewed articles (26. 3\%) were selected the maximum sampled size of 500 participants $(26,27,32,33$, $35)$. The next $15.9 \%$ selected a sample size of $400(80 \%)$ participants $(3,9,17)$ and $15.9 \%$ selected a sample size of $300(60 \%)$ participants $(29,36,40)$. The remaining studies of (10. 6\%) had selected a sample size of $200(40 \%)$ participants $(4,1$ Most of the included studies 9 (34. 3\%)were cross sectional study $(24,26,27,29,30,32,34,38,40)$, followed by $2(10.5 \%)$ were interviews and data from National $(23,33) ; 2(10.5 \%)$ were case control study $(25,36)$. However the remaining reviewed studies $(31.8 \%)$ were literature reviewed (22), Exploratory qualitative research design (25), an interrogative review (28), Formative study (35), and Exploratory descriptive (18). The majority of the included studies $7(36.8 \%)$ were used simple random sampling method $(31,32,33,34,36,38,39)$, followed by systematic Random sampling method 5 (26. 8\%) (24, 25, 27, $29,40)$. The result shows that both data extraction and purposive, non probability sampling method were used as similar rates $(23,30,37)$. Only one study $(5.3 \%)$ was used staged cluster sampling method (26).

Table 1. Distribution of studies based on purpose, design, sample size, sampling method and place conducted.

\begin{tabular}{|c|c|c|c|c|c|c|}
\hline $\begin{array}{l}\text { Author/s } \\
\text { and years }\end{array}$ & $\begin{array}{l}\text { Country And } \\
\text { study setting }\end{array}$ & Purpose & Sample size & Method & $\begin{array}{l}\text { Types of study/ } \\
\text { design }\end{array}$ & $\begin{array}{l}\text { Sampling } \\
\text { method }\end{array}$ \\
\hline $\begin{array}{l}\text { Detekema et } \\
\text { al., } 2012\end{array}$ & $\begin{array}{l}\text { Sub-Saharan } \\
\text { Africa }\end{array}$ & $\begin{array}{l}\text { To identify determinants of male } \\
\text { partners' involvement in MCH } \\
\text { activities, focusing specifically on HIV } \\
\text { prevention of material to child } \\
\text { transmission (PMTCT) in sub- Saharan } \\
\text { Africa. }\end{array}$ & $\begin{array}{l}34 \\
\text { studies }\end{array}$ & Literature review & $\begin{array}{l}\text { Literature } \\
\text { review }\end{array}$ & $\begin{array}{l}\text { Data } \\
\text { extraction }\end{array}$ \\
\hline $\begin{array}{l}\text { Auvinen et } \\
\text { al., } 2014\end{array}$ & $\begin{array}{l}\text { Lusaka, Zambia, } \\
\text { East Africa }\end{array}$ & $\begin{array}{l}\text { To explore the views of Luba-kasai } \\
\text { men, living in Zambia in the Lusaka } \\
\text { Province, on the factors that encourage, } \\
\text { inconvenience or inhibit them in } \\
\text { accompanying their wives to the ANC } \\
\text { clinic and their ideas to improve their } \\
\text { experience. }\end{array}$ & $\begin{array}{l}21 \\
\text { interviewees }\end{array}$ & $\begin{array}{l}\text { Interviews and } \\
\text { data from the } \\
\text { National protocol } \\
\text { guidelines of } \\
\text { Zambia }\end{array}$ & $\begin{array}{l}\text { Interview and } \\
\text { data from the } \\
\text { national } \\
\text { protocol guide } \\
\text { line }\end{array}$ & $\begin{array}{l}\text { Purposive non } \\
\text { probability }\end{array}$ \\
\hline $\begin{array}{l}\text { Alemayehu } \\
\text { et al., } 2014\end{array}$ & $\begin{array}{l}\text { Health Centers, } \\
\text { Tigray Region, } \\
\text { Northern Ethiopia }\end{array}$ & $\begin{array}{l}\text { To point out the role of male partner } \\
\text { involvement on mother's adherence to } \\
\text { PMTCT care and support in Tigray, } \\
\text { Northern Ethiopia. }\end{array}$ & $\begin{array}{l}326 \text { HIV } \\
\text { positive } \\
\text { pregnant } \\
\text { women }\end{array}$ & $\begin{array}{l}\text { Qualitative } \\
\text { methods of data } \\
\text { collection }\end{array}$ & $\begin{array}{l}\text { Cross-sectional } \\
\text { study }\end{array}$ & $\begin{array}{l}\text { Systematic } \\
\text { random } \\
\text { sampling }\end{array}$ \\
\hline $\begin{array}{l}\text { Akarro et al., } \\
2011\end{array}$ & $\begin{array}{l}\text { Ilala Municipality, } \\
\text { Dar salaam region, }\end{array}$ & $\begin{array}{l}\text { To evaluate knowledge, attitude, } \\
\text { communication behaviour among }\end{array}$ & $\begin{array}{l}192 \text { study } \\
\text { units }\end{array}$ & $\begin{array}{l}\text { In-depth } \\
\text { interview }\end{array}$ & Case study & $\begin{array}{l}\text { Systematic } \\
\text { random }\end{array}$ \\
\hline
\end{tabular}




\begin{tabular}{|c|c|c|c|c|c|c|}
\hline $\begin{array}{l}\text { Author/s } \\
\text { and years }\end{array}$ & $\begin{array}{l}\text { Country And } \\
\text { study setting }\end{array}$ & Purpose & Sample size & Method & $\begin{array}{l}\text { Types of study/ } \\
\text { design }\end{array}$ & $\begin{array}{l}\text { Sampling } \\
\text { method }\end{array}$ \\
\hline & Tanzania & $\begin{array}{l}\text { partners, awareness, and how they } \\
\text { affect the uptake of the PMTCT } \\
\text { services are among the factors } \\
\text { considered }\end{array}$ & & & & sampling \\
\hline $\begin{array}{l}\text { Awugafac et } \\
\text { al. , } 2015\end{array}$ & $\begin{array}{l}\text { Tiko health district, } \\
\text { South West Region } \\
\text { of Cameroon }\end{array}$ & $\begin{array}{l}\text { To investigate factors that affect access } \\
\text { to and utilization of material and child } \\
\text { health }(\mathrm{MCH}) \text { and PMTCT services } \\
\text { among women in Tiko Health District }\end{array}$ & 436 women & descriptive & $\begin{array}{l}\text { Cross sectional } \\
\text { study }\end{array}$ & $\begin{array}{l}\text { Two stage } \\
\text { cluster } \\
\text { sampling } \\
\text { method }\end{array}$ \\
\hline $\begin{array}{l}\text { Haile and } \\
\text { Brhan ., } \\
2014\end{array}$ & $\begin{array}{l}\text { Mekelle town } \\
\text { health facilities, } \\
\text { Tigray, } \\
\text { Ethiopia }\end{array}$ & $\begin{array}{l}\text { To determine the level of male partner } \\
\text { involvement in PMTCT and factors } \\
\text { that affecting it. }\end{array}$ & $\begin{array}{l}473 \text { pregnant } \\
\text { mothers }\end{array}$ & Interview & $\begin{array}{l}\text { Cross sectional } \\
\text { study }\end{array}$ & $\begin{array}{l}\text { Systematic } \\
\text { random } \\
\text { sampling }\end{array}$ \\
\hline $\begin{array}{l}\text { Auvinene et } \\
\text { al. , } 2013\end{array}$ & Sub-Saharan Africa & $\begin{array}{l}\text { To describe male involvement in } \\
\text { programmes for preventing mother-to- } \\
\text { child transmission (PMTCT) in sub- } \\
\text { shran Africa. }\end{array}$ & 18 Articles & $\begin{array}{l}\text { An Interrogative } \\
\text { review }\end{array}$ & $\begin{array}{l}\text { An integrative } \\
\text { study }\end{array}$ & $\begin{array}{l}\text { Data retrieved } \\
\text { from the PUB } \\
\text { Med and } \\
\text { Medlin data } \\
\text { base }\end{array}$ \\
\hline $\begin{array}{l}\text { Matongo., } \\
2014\end{array}$ & $\begin{array}{l}\text { ChibombRegional } \\
\text { Refreal Hospital } \\
\text { Bungokho, } \\
\text { Uganda }\end{array}$ & $\begin{array}{l}\text { To determine factors that influence } \\
\text { male involvement in PMTCT programs } \\
\text { in chiboombo district of central } \\
\text { province in Zambia }\end{array}$ & $\begin{array}{l}240 \text { male } \\
\text { participants }\end{array}$ & $\begin{array}{l}\text { Focused group } \\
\text { discussion and } \\
\text { interview }\end{array}$ & $\begin{array}{l}\text { Cross sectional } \\
\text { study }\end{array}$ & $\begin{array}{l}\text { Systematic } \\
\text { Random } \\
\text { Sampling }\end{array}$ \\
\hline $\begin{array}{l}\text { Byamugisha } \\
\text { et al. , } 2010\end{array}$ & $\begin{array}{l}\text { Mbale regional } \\
\text { Refreal Hospital, } \\
\text { Bungokho, Uganda }\end{array}$ & $\begin{array}{l}\text { To determine the level of male } \\
\text { involvement and identify its } \\
\text { determinants in the PMTCT } \\
\text { programme. }\end{array}$ & 338 men & $\begin{array}{l}\text { Qualitative and } \\
\text { quantitative }\end{array}$ & $\begin{array}{l}\text { Cross sectional } \\
\text { study }\end{array}$ & Purposively \\
\hline $\begin{array}{l}\text { Nyondo et } \\
\text { al. , } 2014\end{array}$ & $\begin{array}{l}\text { South Lunzu } \\
\text { Health Centere } \\
\text { (SLHC) in } \\
\text { Blantyre, Malawi }\end{array}$ & $\begin{array}{l}\text { To identify the factors that promote and } \\
\text { those that hinder Male involvement in } \\
\text { PMTCT services in antenatal care } \\
\text { services in Blantyre, Malawi }\end{array}$ & $\begin{array}{l}18 \text { men and } \\
17 \text { pregnant } \\
\text { women }\end{array}$ & $\begin{array}{l}\text { A part of } \\
\text { formative study } \\
\text { on Exploratory } \\
\text { qualitative }\end{array}$ & Formative study & $\begin{array}{l}\text { Randomly } \\
\text { selected }\end{array}$ \\
\hline $\begin{array}{l}\text { Abuhay et } \\
\text { al. , } 2014\end{array}$ & $\begin{array}{l}\text { Sixteen Districts in } \\
\text { Addis Ababa, } \\
\text { Ethiopia }\end{array}$ & $\begin{array}{l}\text { To assess male involvement in } \\
\text { prevention of mother-to-child } \\
\text { transmission of HIV and associated } \\
\text { factors among male partners in Addis } \\
\text { Ababa. }\end{array}$ & $\begin{array}{l}431 \text { male } \\
\text { participants }\end{array}$ & $\begin{array}{l}\text { Qualitative } \\
\text { method }\end{array}$ & $\begin{array}{l}\text { A community } \\
\text { based cross } \\
\text { sectional study }\end{array}$ & $\begin{array}{l}\text { Multi-stage } \\
\text { sampling } \\
\text { simple } \\
\text { random } \\
\text { sampling }\end{array}$ \\
\hline $\begin{array}{l}\text { Osoti et al. } \\
2012\end{array}$ & Ahero, Kenya & $\begin{array}{l}\text { Hypothesized that male partner HIV-1 } \\
\text { counselling and testing during } \\
\text { pregnancy can be increased by offering } \\
\text { couple HIV_1 counselling and testing } \\
\text { (CHCT) at home. }\end{array}$ & $\begin{array}{l}495 \text { pregnant } \\
\text { women }\end{array}$ & $\begin{array}{l}\text { Randomized } \\
\text { controlled trial }\end{array}$ & Interview & $\begin{array}{l}\text { Random } \\
\text { sampling }\end{array}$ \\
\hline $\begin{array}{l}\text { Boniphace, } \\
\text { Y . , } 2009\end{array}$ & $\begin{array}{l}\text { Hedaru Ward in } \\
\text { same } \\
\text { district;Kilimanjar } \\
\text { o, Tanzania }\end{array}$ & $\begin{array}{l}\text { To determine willingness and } \\
\text { participation toward presentation of } \\
\text { MTCT (PMTCT) among males of } \\
\text { reproductive age in Hedaru ward at } \\
\text { same district; Kilimanjaro Region. }\end{array}$ & $\begin{array}{l}138 \text { male of } \\
\text { reproductive } \\
\text { age }\end{array}$ & Descriptive study & $\begin{array}{l}\text { Cross sectional } \\
\text { study }\end{array}$ & $\begin{array}{l}\text { Randomly } \\
\text { selected }\end{array}$ \\
\hline $\begin{array}{l}\text { Kalembo et } \\
\text { al. , } 2013\end{array}$ & $\begin{array}{l}\text { Mwanza District } \\
\text { hospital, south - } \\
\text { East of Lilongwe, } \\
\text { Malawi }\end{array}$ & $\begin{array}{l}\text { To examine the association between } \\
\text { male partner involvement and the } \\
\text { uptake of prevention of PMTCT of } \\
\text { HIV (PMTCT) interventions. }\end{array}$ & $\begin{array}{l}476 \mathrm{HIV} \\
\text { positive } \\
\text { women }\end{array}$ & $\begin{array}{l}\text { Retrospective } \\
\text { cohort study }\end{array}$ & Cohort study & $\begin{array}{l}\text { Retrieved } \\
\text { from patient } \\
\text { card }\end{array}$ \\
\hline $\begin{array}{l}\text { Mnyanietal., } \\
2014\end{array}$ & $\begin{array}{l}\text { Soweto, } \\
\text { Johannesburg, } \\
\text { South Africa }\end{array}$ & $\begin{array}{l}\text { To identify the key patient cantered } \\
\text { risks for MTCT in a high HIV } \\
\text { prevalence setting in Johannesburg, } \\
\text { South Africa. }\end{array}$ & $\begin{array}{l}77 \text { women } \\
\text { with HIV } \\
\text { infected } \\
\text { infants ; } 154 \\
\text { with } \\
\text { uninfected } \\
\text { infants }\end{array}$ & $\begin{array}{l}\text { Case control } \\
\text { study }\end{array}$ & $\begin{array}{l}\text { Case control } \\
\text { study }\end{array}$ & $\begin{array}{l}\text { Randomly } \\
\text { selected }\end{array}$ \\
\hline $\begin{array}{l}\text { Adedimeji et } \\
\text { al. , } 2012\end{array}$ & $\begin{array}{l}\text { Arba Minch, } \\
\text { Gamo Gofa Zone, }\end{array}$ & $\begin{array}{l}\text { To highlight and describe unique } \\
\text { contextual factors contributing to low }\end{array}$ & $\begin{array}{l}10 \\
\text { participants }\end{array}$ & $\begin{array}{l}\text { In-depth } \\
\text { interview and }\end{array}$ & $\begin{array}{l}\text { Exploratory } \\
\text { qualitative }\end{array}$ & Purposive \\
\hline
\end{tabular}




\begin{tabular}{|c|c|c|c|c|c|c|}
\hline $\begin{array}{l}\text { Author/s } \\
\text { and years }\end{array}$ & $\begin{array}{l}\text { Country And } \\
\text { study setting }\end{array}$ & Purpose & Sample size & Method & $\begin{array}{l}\text { Types of study/ } \\
\text { design }\end{array}$ & $\begin{array}{l}\text { Sampling } \\
\text { method }\end{array}$ \\
\hline $\begin{array}{l}\text { Perez, M. , } \\
2010\end{array}$ & $\begin{array}{l}\text { Luzira's prisons } \\
\text { custodial staffs, } \\
\text { Kampala, } \\
\text { Uganda }\end{array}$ & $\begin{array}{l}\text { To assess individual, core prison } \\
\text { services and health services factors that } \\
\text { influence male involvement in PMTCT } \\
\text { programs among Luzira's prisons } \\
\text { custodial staffs. }\end{array}$ & $\begin{array}{l}343 \text { male } \\
\text { custodial } \\
\text { staffs }\end{array}$ & $\begin{array}{l}\text { Qualitative and } \\
\text { quantitative }\end{array}$ & $\begin{array}{l}\text { Cross sectional } \\
\text { study }\end{array}$ & $\begin{array}{l}\text { Randomly } \\
\text { selected }\end{array}$ \\
\hline $\begin{array}{l}\text { Jeewa. Z. , } \\
2014\end{array}$ & $\begin{array}{l}\text { Primary health care } \\
\text { facility in } \\
\text { Kwazulu-Natal, } \\
\text { South Africa }\end{array}$ & $\begin{array}{l}\text { To explore and describe male partner } \\
\text { involvement in PMTCT services in a } \\
\text { selected primary health care facility in } \\
\text { Kwazulu-natal. }\end{array}$ & 90 men & $\begin{array}{l}\text { A qualitative } \\
\text { exploratory } \\
\text { descriptive } \\
\text { design }\end{array}$ & $\begin{array}{l}\text { Exploratory } \\
\text { descriptive }\end{array}$ & $\begin{array}{l}\text { Randomly } \\
\text { selected }\end{array}$ \\
\hline
\end{tabular}

Out of 19 reviewed studies $8(42.2 \%)$ were included in their studied participation when the male partners of pregnant women attending ANC and under five clinics, their involvement in PMTCT services and men aged 18 years or more, whose spouses were attending $\operatorname{ANC}(22,23$, $28,29,30,32,34,39)$. Four of the reviewed articles $(21$. $2 \%$ were included participants in their studies regarding women of reproductive age selected from study areas, with the communities and at the health facilities offering ANC and PMTCT services. All information about participants inclusion criterion in all of selected reviewed article show in (Table 2). As shown in table 2, these reviewed studies sought to generalize from the mentioned articles by identifying a wide variety of male partner's involvement in PMTCT services and associated factors in PMTCT in Africa. These results show the different instruments used to measure male partners involvement and factors which affects in PMTCT services. a structured and pretested self administrated and interview questionnaire, which accounted for $60 \%$ of articles on male partner's involvement in PMTCT services and various factors affects in PMTCT service in Africa measurement were the most commonly used strategy 24, 25, 26, 27, 30, 31, 32, 36, 37, 38, 39, 40), followed by various measurement in each of the remaining studies such as semi structured questionnaire (10.6\%) (29, $34)$, Interview questionnaire and guideline (10.6\%) (23, 25), Data baseline (5. 3\%) (22), Published articles /secondary data (5.3\%) (28), and underwent smart phone audio computer assisted self interview (5. 3\%) (33). The majority of the reviewed studies8 (42. 4\%)were used descriptive and multivariate logistic regression $(24,25,27$, $29,32,35,36,38)$ followed by $2(10.6 \%)$ were used qualitative inductive content analysis $(23,28)$. Two reviewed studies $(10.6 \%)$ thematic content analysis $(31$, $37)$, and $2(10.6 \%)$ were used EPI-Info computer software $(34,39)$. The remaining studies $5(42.4 \%)$ were used
Literature review (22), statistical analysis (26), EPIDA TA (30), and univariate , Bivarate and multivariate analysis (40) were used as data analysis in this reviewed article respectively. The majority of reviewed studies 9 (47. $7 \%)$ were used $(\mathrm{p}<0.05)$ for a significance of the study $(24$, $24,29,32,33,35,36,38,39)$, followed by $4(21.250$ were not used any $\mathrm{P}$-value to measure statistical significance. Two studies $(10.6 \%)$ were measured their result with $\mathrm{P}=0$. 05 during identified significance of the study. However, the remaining four studies (21.2\%) were used odds ratio with $95 \%$ CI (27), the developed themes were verified repeatedly against the digital recordings (31), association between certain variables of interest and male involvement (39), and relevant vibration quotes are reported to aid in the interpretation of the data (37). The result showed a significant relationship between knowledge, attitude and follow up to uptake of PMTCT serious were observed and the communication barriers between pregnant women and their husband /partners are the limiting factors of follow up to uptake and utilization of PMTCT services. The participants had a mean age of 35 years, and the age was not statistically significant ( $\mathrm{P}=0.353$ ), factors such as education, and knowledge of PMTCT had an association with programmes $(25,28,29)$. Knowledge, income, cultural beliefs were significantly predictor of male's involvement in the prevention of mother-to-child transmission of HIV and from the total respondents, only 121 (28. 1\%) of males had high involvement in PMTCT, Younger men and those with a higher education were more willing to be involved than those who were older or those with a lower level of education $(32,37,38,39,40)$. Haile and Brhan (2014) determined the level of male partner involvement in PMTCT services which $20 \%$ of pregnant mothers have been accompanied by their male partner to the ANC /PMTCT services $(27,30)$. In addition, Knowledge of HIV sero status maternal willingness to inform their husband about 
the availability of VCT services in ANC/PMTCT and previous history of couple counseling were found to be the independent predictors of male involvement in ANC /PMTCT services $(27,30,34)$. This reviewed result also indicated that the majority of studies defined male participation as male involvement solely during antenatal HIV testing (22), lack of knowledge, motivation, fear of death, socioeconomic circumstances and gain the arrangements and working culture at the clinic were held as inhibiting factors, the factors that would potentially promote male involvement were categorized into community, health facility and personal or family level factors $(22,23,31)$. The findings were based on adherence rate of mothers towards PMTCT care and support was 84 . $9 \%$. The result was also indicates that HIV positive pregnant mothers with better male involvement had 8 times more odds to adhere to PMTCT care and support as compared to their counterpart (24). Osoti et al (2012) and Kalembo et al (2013) were hypothesized that male partner HIV-1 counseling and testing during pregnancy can be increased by offering couple HIV-1 counseling and testing (CHCT) at home and toward PMTCT among males of reproductive age were found that male partners were significantly more likely to be reached by home based $(88 \%)$ than clinic based (37\%) CHCT $(\mathrm{p}<0 . \quad 001)$. HIV-1 prevalence was $16 \%$ in both men and women tested and male partner involvement was significantly associated with condom use. Inaddition, 3. $7 \%$ had a male partner involvement while $86.3 \%$ had no male partner involvement $(33,35)$ The majority of this reviewed studies $6(31.8 \%)$ were concluded about their finding; level of male involvement in PMTCT programs was associated with knowledge of PMTCT $(24,34,36)$ and structured and cultural barriers to men's involvement in the PMTCT program were complex and interrelated $(30,31,32)$. Both stigmatization is singled out as a matter to be addressed and the uptake of MCH/PMTCT services was high in the study $(25,26,35,37)$. The remaining studies $(26.5 \%)$ were concluded as follow: many challenges to increase male involvement in PMTCT (22), enhance male participation in the process (23), the adherence rate of mothers towards PMTCT care and support was fair (24), highlight the male participation in PMTCT programs (28), and male partner involvement in ANC/PMTCT is low (27).

Table 2. Distribution of studies based on instruments, participants, data analysis and results.

\begin{tabular}{|c|c|c|c|c|c|}
\hline $\begin{array}{l}\text { Author/s and } \\
\text { years }\end{array}$ & participants & Instruments & Data analysis & P-value & Result \\
\hline $\begin{array}{l}\text { Detekema et } \\
\text { al. , } 2012\end{array}$ & $\begin{array}{l}\text { Male partners of pregnant } \\
\text { women attending antenatal } \\
\text { and under five clinics. } \\
\text {-The male partner may be the } \\
\text { baby's father or not. }\end{array}$ & Data bases & Literature Review & NA & $\begin{array}{l}\text { - Male participation as male involvement } \\
\text { solely during antenatal HIV testing }\end{array}$ \\
\hline $\begin{array}{l}\text { Auvinen et } \\
\text { al. , } 2014\end{array}$ & $\begin{array}{l}\text { Luba - Kasai men who were } \\
\text { either refugees from the } \\
\text { democratic republic of the } \\
\text { Congo or descendants of } \\
\text { Congolese Refugees. }\end{array}$ & $\begin{array}{l}\text { Interview } \\
\text { questionnaire } \\
\text { and Guideline }\end{array}$ & $\begin{array}{l}\text { Twenty-one } \\
\text { Interviews were } \\
\text { analyzed using } \\
\text { qualitative inductive } \\
\text { content analysis and } \\
\text { deductive content } \\
\text { analysis }\end{array}$ & NA & $\begin{array}{l}\text { A lack of motivation, fear of death } \\
\text { socioeconomic circumstances and gain the } \\
\text { arrangements and working culture at clinic } \\
\text { were held as inhibiting factors }\end{array}$ \\
\hline $\begin{array}{l}\text { Alemayehu et } \\
\text { al. , } 2014\end{array}$ & $\begin{array}{l}\text { Among HIV positive } \\
\text { pregnant women attending } \\
\text { ART }\end{array}$ & $\begin{array}{l}\text { Structured } \\
\text { and pre tested } \\
\text { questionnaire }\end{array}$ & $\begin{array}{l}\text { Entered into cleaned } \\
\text { in EPI Data version } \\
3.1 \text { and using SPSS } \\
20 \text { for windows, } \\
\text { Descriptive and } \\
\text { multivariate logistic } \\
\text { regression }\end{array}$ & $\begin{array}{l}\text { A p-value of } \\
\text { less than } 0.05 \\
\text { was set for the } \\
\text { significance of } \\
\text { estimates }\end{array}$ & $\begin{array}{l}\text { The adherence rate of mothers towards } \\
\text { PMTCT care and support was } 84.9 \% \text {. } \\
\text { HIV positive pregnant mothers with better } \\
\text { male involvement had } 8 \text { times more odds } \\
\text { to adhere to PMTCT care and support as } \\
\text { compared to their counterpart }\end{array}$ \\
\hline $\begin{array}{l}\text { Akarro et al. } \\
2011\end{array}$ & $\begin{array}{l}\text { Questions relating to uptake } \\
\text { of PMTCT and associated } \\
\text { factors such as outlined in } \\
\text { the introduction were asked }\end{array}$ & $\begin{array}{l}\text { Structured, } \\
\text { administered } \\
\text { questionnaire } \\
\text { and in-depth } \\
\text { interviews }\end{array}$ & $\begin{array}{l}\text { Using SPSS chi- } \\
\text { square test and } \\
\text { logistic regression } \\
\text { modules }\end{array}$ & $\begin{array}{l}\text { P-value of }<0 \text {. } \\
05\end{array}$ & $\begin{array}{l}\text { A significant relationship between } \\
\text { knowledge (Attitude and follow up to the } \\
\text { uptake of PMTCT services were observed. } \\
\text { The communication barriers between } \\
\text { pregnant women and their } \\
\text { husband/partners are the limiting factors of } \\
\text { follow up to uptake and utilization of } \\
\text { PMTCT services. }\end{array}$ \\
\hline $\begin{array}{l}\text { Awugafac et } \\
\text { al. , } 2015\end{array}$ & $\begin{array}{l}\text { Women of reproductive age } \\
\text { selected from two settings. } \\
\text { With } \mathrm{n} \text { the communities and } \\
\text { at the health facilities } \\
\text { offering ANC and PMTCT } \\
\text { services in the Tiko Health } \\
\text { District }\end{array}$ & $\begin{array}{l}\text { Administered } \\
\text { face to face } \\
\text { interviews }\end{array}$ & $\begin{array}{l}\text { Entered and } \\
\text { analyzed with Epi- } \\
\text { Info statistical } \\
\text { software version } 3 \text {. } \\
5 \text {. }\end{array}$ & $\begin{array}{l}\text { Relationships } \\
\text { between the } \\
\text { variables were } \\
\text { established } \\
\text { using the chi- } \\
\text { square test at } \\
\mathrm{P}=0.05\end{array}$ & $\begin{array}{l}98.4 \% \text { of them attended antenatal (ANC) } \\
\text { during their most recent pregnancy. No } \\
\text { education and acquisition of primary } \\
\text { education was associated with better male } \\
\text { partner involvement in PMTCT }\end{array}$ \\
\hline $\begin{array}{l}\text { Haile and } \\
\text { Brhan ., } 2014\end{array}$ & $\begin{array}{l}\text { Pregnant mothers who were } \\
\text { attending antenatal care } \\
\text { (ANC/PMTCT) at five } \\
\text { randomly selected health }\end{array}$ & $\begin{array}{l}\text { Interview } \\
\text { administered } \\
\text { structured } \\
\text { Interviews }\end{array}$ & $\begin{array}{l}\text { Entered into EPI } \\
\text { software version } 3 . \\
\text { 5. 2, edited, cleaned } \\
\text { and analyzed using }\end{array}$ & $\begin{array}{l}\text { Odds ratio with } \\
95 \% \text { confidence } \\
\text { interval }\end{array}$ & $\begin{array}{l}20 \% \text { of pregnant mothers have been } \\
\text { accompanied by their male partner to the } \\
\text { ANC/PMTCT services. }\end{array}$ \\
\hline
\end{tabular}




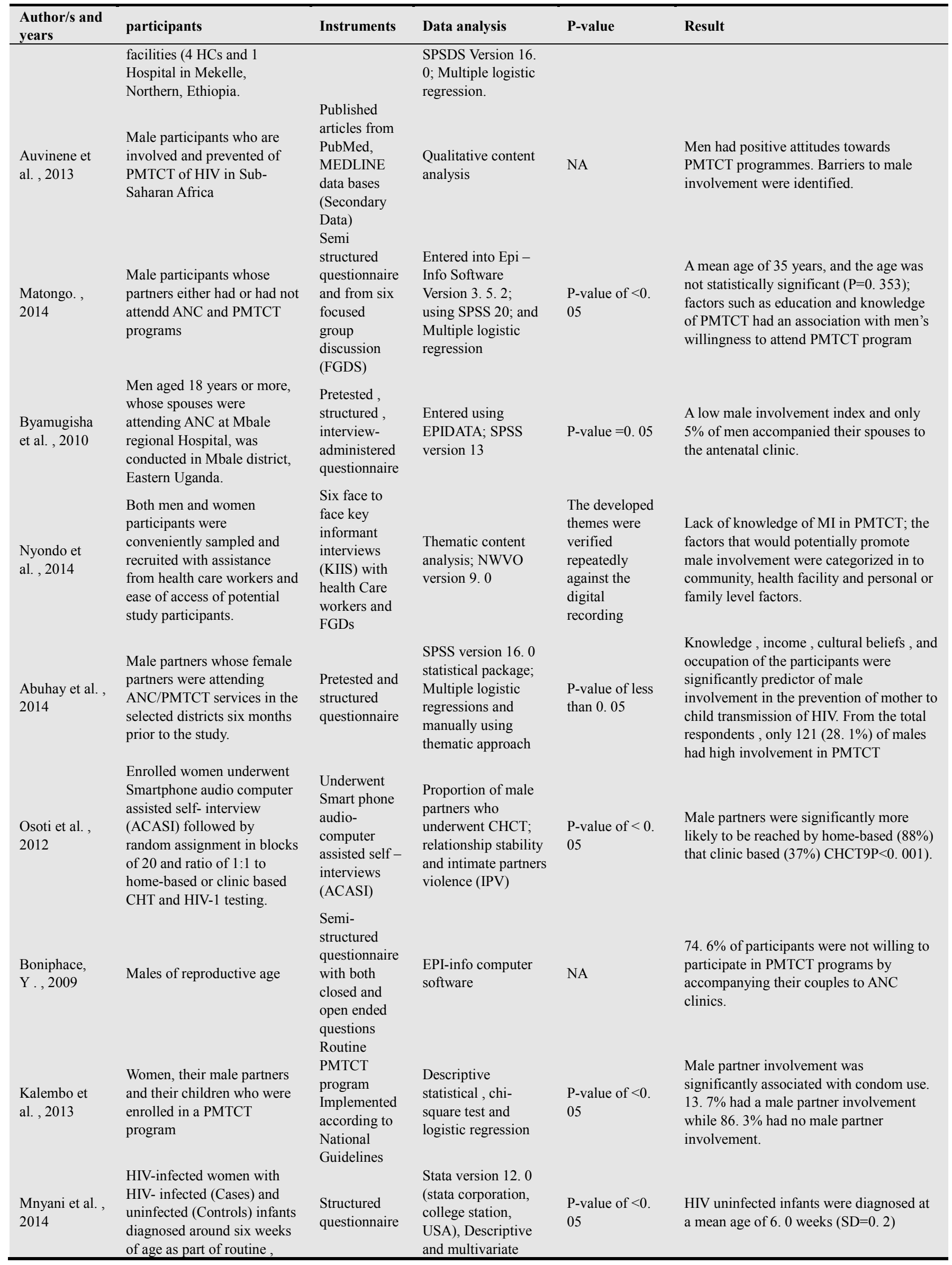




\begin{tabular}{|c|c|c|c|c|c|}
\hline $\begin{array}{l}\text { Author/s and } \\
\text { years }\end{array}$ & participants & Instruments & Data analysis & P-value & Result \\
\hline $\begin{array}{l}\text { Adedimeji et } \\
\text { al. , } 2012\end{array}$ & $\begin{array}{l}\text { Antenatal clinic attendees, } \\
\text { health workers health } \\
\text { facilities in the study area }\end{array}$ & $\begin{array}{l}\text { Interviews } \\
\text { and } \\
\text { discussion } \\
\text { groups }\end{array}$ & $\begin{array}{l}\text { NVIVO Version } 9 \\
\text { for qualitative; } \\
\text { thematic frame work }\end{array}$ & $\begin{array}{l}\text { Relevant } \\
\text { vibration quotes } \\
\text { are reported to } \\
\text { aid in the } \\
\text { interpretation of } \\
\text { the data }\end{array}$ & $\begin{array}{l}\text { Awareness of PMTCT services and } \\
\text { knowledge of its benefits was really } \\
\text { universal, lack of appropriate follow up } \\
\text { mechanisms and inadequate access to ARV } \\
\text { drugs. }\end{array}$ \\
\hline $\begin{array}{l}\text { Jeewa. Z. , } \\
2014\end{array}$ & $\begin{array}{l}\text { Men who are attended in } \\
\text { primary health care facility } \\
\text { in Kwazulu-Natal. }\end{array}$ & $\begin{array}{l}\text { Intervieradmi } \\
\text { nstedred } \\
\text { questionnaire }\end{array}$ & $\begin{array}{l}\text { Association between } \\
\text { certain variables of } \\
\text { interest and male } \\
\text { involvement }\end{array}$ & $\begin{array}{l}\text { Association } \\
\text { between certain } \\
\text { variables of } \\
\text { interest and } \\
\text { male } \\
\text { involvement }\end{array}$ & $\begin{array}{l}\text { Most of the participants indicated that they } \\
\text { were aware of the PMTCT program. }\end{array}$ \\
\hline $\begin{array}{l}\text { Abajobir and } \\
\text { Zeleke. , } 2013\end{array}$ & $\begin{array}{l}\text { Pregnant women who were } \\
\text { attending ANC clinic }\end{array}$ & $\begin{array}{l}\text { Structured } \\
\text { interview } \\
\text { administered } \\
\text { questionnaire }\end{array}$ & $\begin{array}{l}\text { EPi info and } \\
\text { analyzed by using } \\
\text { SPSS software for } \\
\text { windows; } \\
\text { Univariate, } \\
\text { Bivariate and } \\
\text { Multivariate } \\
\text { analyses }\end{array}$ & $\begin{array}{l}\text { P-value of }<0 \text {. } \\
05\end{array}$ & $\begin{array}{l}\text { 82. } 3 \% \text { mother knew about prevention of } \\
\text { mother-to-child transmission of HIV and } \\
97.4 \% \text { had good attitude towards it. ANC } \\
\text { visit of four and above for the current } \\
\text { pregnancy found to have statistically } \\
\text { significant association. }\end{array}$ \\
\hline
\end{tabular}

\section{Discussion}

The above results demonstrate that factors which affects male involvement in PMTCT services in Africa. The earliest study was reported in 2009 (13), and the most recent study was reported in 2015 (5). This section (1)discuss the characteristics of male partner's involvement in PMTCT services in Africa, (2) explores the view of male partner's on the factors that encourage, inconvenience or inhibit them in accompanying their wives to the ANC clinic, (3) describes instruments used to measure male partner's involvement in PMTCT services and various factors which affects PMTCT services, (4) effects of PMTCT services, (5) describes the role of male partner involvement on mother's adherence to PMTCT care support in Africa. We identified only 19 studies, the majority of them (64\%) analyzed the determinants of male partner's involvement in $\mathrm{MCH}$ activities, focusing specifically on HIV prevention of maternal to child transmission (PMTCT) in Africa, and knowledge, attitude, practice and factors associated with PMTCT of HIV among pregnant mother attending ANC. A similar study was conducted by Matongo, LH (2014) and Byamugisha et al (2010) who are explored determinants of male involvement in PMTCT programs in Chibombo district of central province of Zambia. When male partner's take part in the prevention of mother -to-child transmission (PMTCT) of HIV , their knowledge to HIV increases, they become supportive to their partners and their response to HIV testing improves ( 41, 42). Auvinen et al (2014) found that male participation in the prevention of mother-to-child transmission (PMTCT) of HIV has been determined as one of the key factors in sub-sharan African countries (43). This research showed that the majority of reviewed studies were used simple random sampling method . In addition, the subjects, who had enrolled in the reviewed studies, were male partners of pregnant women attending ANC and under five clinics, their involvement in PMTCT services, and men aged 18 years or more whose spouses were volunteer participation. The outcome measurements were accurate. Perhaps using non-random sampling methods in selecting participants for determinants of male involvement in PMTCT services should not be considered in future researchers to minimize bias because of volunteer participate. The review revealed several carefully developed instruments and analytic approaches for measuring male partner's involvement in PMTCT services and associated factors in PMTCT services in Africa. While these measures were developed for a specific study, structured and pretested self administered and interview questionnaire which accounted for $67 \%$ of reviewed studies on male partner's involvement in PMTCT services and various factors affects in PMTCT services in Africa, was the most used strategy. Nine of the reviewed studies explored the determinant of male partner's involvement in PMTCT and associated factors in PMTCT services. In this regard, the majority (47. $7 \%$ ) of male partner's reported that they were visited ANC/PMTCT clinic with their wives. This instrument can provide a useful stepping stone for the further study of factors which affects male partner's involvement in PMTCT service in Africa. In some studies, the measurement were taken as part of an instrument; however, it is important to use them as measures to identify the factors affecting of male involvement in PMTCT services, and, and to better understand to investigate the method of response to male involvement in 
PMTCT services. In contrast, Ditekemena et al (2012) found that the male partner's participation is a crucial component in the optimization of PMTCT service. For this reason, ANC/PMTCT is the only opportunity to capture pregnant mothers and their male partner's to prevent the transmission of HIV during pregnancy, labor, and breast feeding $(22,44,45$, 46). This finding has efforts to involve men in ANC services, where PMTCT takes place, have only resulted in a few husbands being involved in PMTCT services have been criticized for bony focusing on females and sidelining males who are the primary support unit to the women (47). The majority of this review studies utilized quantitative and qualitative studies approaches to answer the research questions. Meanwhile, a few studies were using only qualitative method which helps to collect, analyze, and interpret data. They used this method to assess phenomenon, process, prospective and views of Male partner's in PMTCT Services. The majority of reviewed studies frequently used descriptive statistics and multivariate logistic regression to compute study variables and socioeconomic characteristics. This is consistent with a study conducted by male participation in child bearing decisions is crucial and also has a positive impact on the acceptability of PMTCT interventions $(47,48)$. The age was not statistically significant, factors such as education, and knowledge of PMTCT had an associated with men's willingness to attend PMTCT programmes. Knowledge, income, cultural beliefs were significantly predictor of male's involvement in the prevention of mother to child transmission of HIV and male $\mathrm{s}$ had high involvement in PMTCT. Kalembo et al (2013) and Aluisoo eta al (2011) found that male partner involvement increases the uptake of some PMTCT interventions by HIV positive women. Multi strategic, culturally tailored public health care models are needed to increase the rate of male partner involvement in the program (41), statistically significant associated between male partner involvement and infant HIV transmission rate $(44,45)$. This finding is consistent with by Irin., 2009; Averting HIV and AIDS or Avert. , 2009) who found that whether men accompanying their partners had any significant influence on attendance levels. The study finding also showed that when women are supported and accompanied by their spouses, it improved their clinic attendance levels $(44,45,46,47,48,49,50)$.

\section{Conclusion}

The implications of this review are significant in certain areas which worth further research . Further research must look at the impacts of different types of male partner's involvement in PMTCT services. It is proposed that male partner's participation in PMTCT services improves as the male partners gain PMTCT services experiences in their long life with in specific and general characteristics and with experience, male partners gain a sense of saliency in relation to their involvement in PMTCT services and motivate their wives. Male partners may use PMTCT in HIV services independently and eonccerrently to solve weak and long time PMTCT services at health facilities. Finally, future researches must use rigorous methodology to elicit the real impacts of male partner's involvement in PMTCT services and their factors which affect PMTCT services. Suggestions for future research are also mentioned . perhaps the implications discussed in this review are not only confined to medical students, but also can be utilized by researchers of other disciplines as a guide line to design, plan and conduct similar researches in their own settings. Use of similar health measurements for comparison of outcomes in the future researches is recommended.

\section{Acknowledgements}

It is hereby acknowledged colleagues and all those who associated in conducting the study or critiquing the manuscript. We are grateful to all persons who provided technical help in this study and assisted in writing the manuscript.

\section{Authors' Contribution}

Development of the original idea and protocol data abstraction and analyses, writing the manuscript: Addis Adera Gebru, Mesfine Wudu and Yonas Yimam Ayene: and Development of the protocol, overall Guide data abstraction, preparing the manuscript: Markos Kidane Assefa, Ambachew Woreta Hailu and Tigabu Molla.

\section{References}

[1] WHO: Global HIV/AIDS response Epidemic update and health sector progress towards universal access, progress report 2011. Geneva: World Health Organization; 2011. http://www.who.int/hiv/pub/progress-report2011.

[2] Dunkle, KL., Stephenson, R., Karita, E., Chomba, E., Kayitenkore, K., Vwalika, C., Greenberg, L., Allen, S (2008). New heterosexually transmitted HIV infections in married or cohabiting couples in Urban Zambia and Rwanda: an analysis of survey and clinical data. Lancet 371; 2183-2191.

[3] Matovu, IK., Makumbi, FE (2007). Expanding access to voluntary HIV counseling and testing in Sub-Sharan Africa: Alternative approaches for improving uptake, 2001-2007. Trop Med Int Health: 12:1315-1322.

[4] Chigluedere, P., Seage, GR., Lee, TH., Essex, M (2008). Efficacy of ARV-drugs in reducing MTCT of HIV in Africa: a meta-analysis of published clinical trials. AIDS research and human Retroviruses 28: 827-837.

[5] Horvath, T., Madi, BC, Iuppa, IM, Kennedy, GE, Rutherford, G., Read, JS (2010). Interventions for preventing late postnatal MTCT of HIV. Cochrane Data base of systemeatic Reviews. 2009, (1):CD 006734. DOI. 10. 1002 /15651858. CD006734.pub2.

[6] WHO (2010). Prevention of Mother-to-child transmission of HIV strategies vision 2010-2015: Preventing mother-to-child transmission of HIV to reach the UNGASS and Millennium Development Goals. Geneva 2010-2015. 
[7] Peltezer, K., Jones, D., Weiss, SM., Shikwane, E. (2011). Promoting male involevemnttp0 improve PMTCT uptake and reduce antenatal HIV infection: a cluster randomized controlled trial protocol. BMC Public Health, 778: doi. 10.1186/1471-2458-11-778. http://www.biomedcentral. com/content/pdf/1471-2458-11-778.pdf.

[8] Falnes, Eli, F. , Moland, M. , Tylleskar, T. , Manuela, De Padi, M. , Msuya, E. , Engebretsen, I (2011). It is her responsibilling: Partner involvement in Prevention of mother-to-child transmission of HIV programmes Northern Tanzania. Jint AIDS Soc. 2011, 14 (21): doi. 10.1186/1758-2652-14-21.

[9] Lyatuu, MB, Msamanga, G. , Kalinga, AK (2008). Client's satisfaction with services for prevention of mother to child transmission of HIV in Ddoma rural district. East Afr J Public Health . 5:174-179.

[10] Msuya, SE. , Mbizvo, EM. , Hussain, A. , Uriyo, J. , Sam, AVE. , Stray-pedensen, B (2008). Low male partner participation in antenatal HIV counseling and testing in Northern Tanzania: Implication for preventive programs. AIDS care: Psychological and Socio. Medical Aspects of AIDS/HIV. 20: 700-709.

[11] Benkel, RG (2007). Male involvement and participation in prevention of mother to child transmission (PMTCT) of HIV /AIDS: the case of chipata district . In Bachelors University of Zambia. Department of Nursing, 2007.

[12] Musya, SE. , Mbizvo, EM. , Hussain, A. , Uriyo, J. , Sam, NE. , Stray, Pedersen, B (2008). Low male partner participation in antenatal HIV counseling and testing in Northern Tanzania: Implications for preventive programs. AIDS Care . 2096): 700-709.

[13] WHO, UNICEF (2007). New guidance on global scale up of the prevention of mother-to-child transmission of HIV: towards universal access for women, infants and young children and eliminating HIV/AIDS among children, wwitzerl and, World Health Organization HIV/AIDS Department.

[14] WHO (2010). Mother-to-child transmission of HIV available. http://www. who. int (hiv/topics/mtct/en/index. html. Accessed 2015 April . 13.

[15] Mbonye, A. , Garcia-Moreno, C. , MCGill, S. , Maman, S. (2010). Barriers to prevention of mother-to-child transmission of HIV services in Uganda, Journal of Biosocial Sciences: 42 (2):271.

[16] Techav, K. , Kalk, E. , Coovadia, A., Black, V., Pickerill, S. , Mellins, CA. , Abrams, EJ., Strehlav, R., Kuhn, L (2014). Timing of maternal HIV testing and uptake of prevention of mother-to-child transmission interventions among women and their infected infants in Johannesburg, South Africa. J Acquir Immune Defic Syndr. 65:e170-e178.

[17] Chibwesha, CJ. , Giganti, MJ. , Putta, N. , Chintu, N. , Mulindwa, J. , Dorto, BJ. , Chi, BH. , Striger, JS. , Stringer, EM (2011). Optimal time on HAART for prevention of mother-to-child transmission of HIV . J Acquir Immune Defic Syndr 58 (2): 224-228.

[18] World Health Organization, "Prevention of mother to child transmission (PMTCT) . Briefing note. Department of HIV /AIDS, "2007, http://www. who. int/hiv/pub/toolkits/PMTCT\%20HIV\%20Dep\%brief $\$ 20$ oct\% 2007.pdf.
[19] Siegfrid, N. , Vander Merwe, L., Brocklchurst, P. , Sint, TT (2011). "Antiretrovirals for reducing the risk of mother -tochild transmission of HIV infection," Cochrane Database of systematic Review, No7. pCD03510, 2011.

[20] WHO (2009). Rapid advice: use of antiretroviral drugs for treating pregnant women and preventing HIV infection in Infants. Genevea, World Health Organization.

[21] Effective Public Health Practice Project (2009). Quality Assessment Tool for Qualitative studies. EPHPP. (updated 2009). Available from: http://www.ephpp.ca/tools.html.

[22] Ditekemana, J. , Koole, O. , Engmann, C. , Matendo, R. , Tshefu, A. , Ryder, R. , Colebunders, R (2012). Determinants of male involvement in maternal and child health services in sub-saharan Africa: a review. Reproductive health. 9:32:1-8. http://www.reproductive-health-journal.com/content/9/1/32.

[23] Auvienen, J. , Kylma, J. , Valimaki, M. , Bweupe, M. , Suomineen, T (2014). Luba-Kasai men and the prevention of mother to child transmission (PMTCT) of HIV program in Lusaka. Health Promotion Interventional Advance Access Published. Doi. 10. 1093/heapro/dat088.

[24] Alemayehu, M. , Etana, B. , Fissheha, G. , Haileselassie, K. , Yebeyo, H. , Berhe, Y. , Ashebir, F (2014). The role of male partner's involvement on mother's adherence of PMTCT cares support, Tigray, Northern Ethiopia. Fam Med Sci Res 3 (4):17: http://dx.doi.org/10.4172/2327-4972.1000137.

[25] Akarro, RR. J, Deonisia, M. , Sichona, FJ (2011). An evaluation of male involvement on the programme for PMTCT of HIV/AIDS: A case study of Ilala Municipality in Dares salaam, Tanzania. 2011:1. http://connection,ebscohost.com/C/articles/9025 3867/evaluation-male-involevemnt - programme-pmtct-hivaids-case-study-ilala-municipality-dases-salaam-tanzania.

[26] Awungafac, G. , Njukens, PA., Ndasi, JA. , Mbuagbaw, LT (2015). Prevention of mother-to-child transmission of the Human Immunodeficiency Virus: Investigating the uptake and utilization of material and child health services in TIKo health district, Cameroon. Pan Africa Medical Journal . 20:20 doi. 10. 11604/pamj. 2015. 20. 20. 5137. http://www.Panafrican-medjournal.com/content/article/20/20/full/.

[27] Haile, F. , Brhan, Y (2014). Male partner involvements in PMTCT: a cross sectional study, Mekelle, Northern Ethiopia. BMC Pregnancy and childbirth. 14:65:1-6. http://www. biomedicenteral. com/1471-2393/14/65.

[28] Auvienen, J. , Kylma, J. , Suominen, T (2013). Male involvement and prevention of mother-to-child transmission of HIV in Sub-Sharan Africa : An integrative review. Current HIVB research, 11 (2): 169-177.

[29] Matongo, LH (2014). Exploring determinants of male involvement in PMTCT programs in Chibombo district of central province of Zambia. Asian Journal Multidisciplinary studies. 2 (12):1.

[30] Byamugisha, R. , Tumwine, JK, Semiyaga, N, N. , Tylleskar, $\mathrm{T}$ (2010). Determinants of male involvement in the prevention of mother-to-child transmission of HIV programme in Eastern Uganda. A cross-sectional Survey. Reproductive Health. $7: 12: 29$ com/content $/ 7 / 1 / 12$ http://www.reproductivehealth journal. 
[31] Nyondo, AL. , Chimwaza, AF. , Muula, AS (2014). Stakeholders' perceptions on factors influencing male involvement in prevention of mother-to-child transmission of HIV services in Blantyre, Malawi. BMC public Health. 14:691:1-15. http://www.biomedcentral.com/1471$2458 / 14 / 691$.

[32] Abuhay, Y. , Abebe, L. , Fentahun, N (2014). Male involvement in prevention of mother-to-child transmission of HIV and associated factors among males in Addis Ababa, Ethiopia. Americaian Journal of Health Research. 296): 338343. doi. 10. 11648/j. aijhr. 20140206. 13. http://www.Sciencepublishinggroup.com/j/ajhr.

[33] Osoti, A. , John-stewart, G. , Richardson, B. , James, K. , Kinuthia, J. , Krakowiak-Redd, D. , Farquhar, C (2012). Home visits during antenatal care enhance male partners HIV-1 counseling and testing during pregnancy in Kenya: a Randomized controlled trial. TUACO103-oral Abstract session. Reterieved by April, 2015.

[34] Boniphace, Y (MD5MUHAS-2008/2009). Willingness and participation toward prevention of mother to child transimission among males of reproductive age: A study from Killmanjaro-Tanzania. Office Publication of the Tanzania Medical Students'Association. 23-26.

[35] Kalembo, FW, Zgambo, M. , Mulaga, AN. , Yukali, D. , Ahmed, NI (2013). Association between male partner involvement and the uptake of prevention of mother-to-child transmission of HIV (PMTCT) interventions in Mwanza district, Malawi: A Retrospective Cohort study. PLOS ONE . 8 (6): e66517. doi. 10. 1371/Journal. Phone. 0066517.

[36] Mnyani, CN, Simango, A. , Murphy, J. , Cherisich, M. , Mclntyre, J (2014). Patient factors to target for eliminations of mother-to-child transmission of HIV. Globalization and Health. 10 (36):1-7. http://www.globalization and health. com/content $/ 10 / 1 / 36$.

[37] Adedimeji, A. , Abdoud, N. , Merdekios, B. , Shivered, M (2012). A qualitative study of barriers to effectiveness of Interventions to prevent mother-to-child transmission of HIV in Arba Minch, Ethiopia. Hindawi Publishing Corporation International Journal of population Research. ID532154:7doi:10.1155/2012/532154.

[38] Perez, M (2010). Factors influencing male involvement in prevention of mother-to-child transmission of HIV program among Luzira's Prison Custodial Staff, Kanpala, Uganda. http://hdl.handle.net/10570/1303.

[39] Jeewa, Z (2014). Male involvement Highlighted in KZN study on pregnant women. 2 (19): 1. http://ndabaonline. Ukzn. ac. za/ukzandabastory/Ndabaonline-vol-2-issue19-college-0f$\mathrm{ht} / \mathrm{male} \% 20$ involvement $\% 20$ highlighted $\% 20$ in partner $\% 20$ KZN\%20study $\% 200 \mathrm{n} \% 20$ pregnant $\% 20$ women/. Abajobir, AA. , Zeleke, AB (2013). Knoweldge, attitude, practice and factors associated with prevention of mother-to-child transmission of HIV /AIDS among pregnant mothers attendning antenatal clinic in Hawassa Referral Hospital, South Ethiopia J AIDS Clin Res . 4 (6):1-7. http://dx.doi.org/10. 4172/2155-6113. 1000215.
[40] Abajobir, AA. , Zeleke, AB (2013). Knowledge, attitude, practice and factors associated with prevention of mother-tochild transmission of HIV/AIDS among pregnant mothers attending antenatal clinic in Hawassa referral Hospital, South Ethiopia. J AIDS ClinRes. 4960; 1-7. http;//dx doi.org/10.4172/2155-6113. 100215.

[41] Matongo, LH (2014). Exploring determinants of male involvement in PMTCT programs in Chibombo district of central province of Zambia . Asian Jouranl Multidisciplinary. 2 (12): $1-2$.

[42] Byamugisha, R. , Tumwine, K. , Semoygaga, N. , Tylleskar, T, $\mathrm{T}$ (2010). Determinants of male involvement in the prevention of mother-to-child transmission of HIV program in Eastern Uganda. Reproductive health 2010, 7:12. Available online http:/www.Reproductive -health -journal. com/context/7/1/12.

[43] Auvinene, J. , Kyma, J. , Valimaki, M. , Buleupe, M. Suominene, T (2014). Luba-Kassai men and the prevention of mother-to-child transmission (PMTCT) of HIV program in Lusaka. Health promotion International Advance Access Published . Doi. 10. 1093/heaproddato88. http://heapro.oxfordjournals.org.on may, 20, 2015.

[44] Gebru, AD. , Kassaw, MW. , Ayene, YY. , Semene, ZM. , Assefa, M. , Hailu, AW (2015). Factors that Affects Male Partner Involvement in PMTCT Services in Africa: A Review Literature. Science Journal of Public Health. Vol. 3, No. 4, 2015, pp. 460-467. doi: 10. 11648/j. sjph. 20150304. 13

[45] Aluissoo, A. , Richardson, A. , Bosire, R. , Stewart, G. , Mbori-Ngacha, D et al (2011). Male antenatal attendance and HIV testing are associated with decreased infant HIV infection and increased HIV-free survival in Nairobi, Kenya. J Aquir Immune DeficSyndr 56:76-82.

[46] Ditekemana, J. , Koole, O. , Matendo, R. , Tshefu, A. , Ryder, R. Colebunders, R (2012). Determinants of male involvement in maternal and child health services in SubSaharan Africa a review . BMC Reprod Health 9 (32):1-6. doi:10.1186/1742-4755-9-32.

[47] Godana, W. , Abraham Atta, A (2013). Prevalence of HIV/AIDS and its Associated Factors among Prevention of Mother-to-Child Transmission (PMTCT) Service Users in Jinka Town Health Institutions, South Omo Zone, South Ethiopia. Science Journal of Public Health. 1 (3):125-130. doi: 10.11648/j.sjph.20130103. 13

[48] Reece, M. , Holub, A. , Nangami, M. , lane, K (2010). Assessing males pousalengagnement with prevention of mother-to-child transmission (PMTCT) program in women in Western Kenya. AIDSCare:22 (6):743-750.

[49] Aluisio, A. , Richardson, BA. Bosire, R. , John-stewart, G. , Mbori-Ngacha, D. , Farquhar, C (2011). Male antenatal attendance and HIV testing are associated with decreased HIV free survival. J Acquire Immune DeficSyndr 56 (1):76-82.

[50] Abuhay, Y. , Abebe, L. , Fentahun, N (2014). Male Involvement in Prevention of Mother to Child Transmission of HIV and Associated Factors among Males in Addis Ababa, Ethiopia. American Journal of Health Research. 2 (6): 338343. doi: 10. 11648/j.ajhr.20140206. 13 